\title{
SISTEM EKONOMI LAISSEZ FAIRE ADAM SMITH
}

Oleh

Devita Ayu Fildayanti//90100118020

email: devita29.akt@gmail.com

Para ahli ekonomi dunia menilai bahwa pemikiran ahli-ahli ekonomi klasik yang dimotori oleh Adam Smith merupakan dasar sistem ekonomi kapitalis. Tokoh-tokoh mazhab klasik mengemukakan bahwa segala kegiatan ekonomi yang dilaksanakan secara bebas dinilai akan lebih banyak manfaatnya bagi kalangan masyarakat secara keseluruhan jika dibandingkan segalanya diatur pemerintah (Agustiati, 2009). Dalam sebuah teori ekonomi makro, kemajuan ekonomi pada tingkat individu maupun bangsa dapat diukur dengan tingkat produktivitasnya maka negara tersebut semakin tinggi pula kemajuan ekonominya. Berbeda lagi jika semakin rendah tingkat produktivitasnya, maka negara tersebut rendah pula kemajuan ekonominya (Cholidiyah, 2018). Mazhab klasik muncul di akhir abad 18 dan awal abad 19 yaitu pada masa revolusi industri. Tokoh mazhab klasik antara lain Adam Smith (1729 - 1790), Jeremy Bentham (1748 -1832), Thomas Robert Malthus (1766 - 1834), Jean Baptiste Say (1767 - 1832), Robert Owen (1771 - 1858), David Ricardo (1772 - 1823), Antoine Augustin Cournot (1801 - 1877) dan John Stuart Mill (1806 - 1873) (Atmanti, 2017).

Sistem ekonomi kapitalis merupakan suatu sistem yang menyandarkan diri sepenuhnya pada hak milik swasta (Private Property) yaitu menjamin bahwa setiap orang mempunyai hak untuk mencapai barang-barang ekonomi dan sumber-sumber daya melalui cara yang legal, mengadakan perjanjian-perjanjian sehubungan dengan hak alamiah terlepas dari kekuasaan Negara, dibina oleh tangan yang tak terlihat (The Invisibel Hand), individualisme ekonomi LaissezFaire yang diartikan bahwa tiadanya intervensi pemerintah akan menyebabkan timbulnya individualism ekonomi dan kebebasan ekonomi. Intervensi pemerintah dibatasi pada aktivitas-aktivitas tertentu, persaingan dan pasar-pasar bebas (free market competition). Prinsip bekerjanya mekanisme pasar menyebabkan 
terjadinya persaingan (Agustiati, 2009). Pada periode ini, tepatnya kapitalisme memulai dan meletakkan pondasi dasarnya, yaitu laisez faire sebagai doktrin mutlak Adam Smith (Hasan et al., 2020). Gaya Kepemimpinan Laissez Faire, yaitu gaya kepemimpinan yang lebih mengutamakan relation oriented (orientasi hubungan) dari pada result oriented (penyelesaian tugas) (Tumbol et al., 2014)

Adam Smith dilahirkan di Skotlandia pada tahun 1723. Karya Smith selain The Wealth of Nations adalah The Theory of Moral Sentiments yang diterbitkan pada tahun 1759 dan catatan saat menjadi mahasiswa pada tahun 1763 yaitu Lectures on Justice, Police, Revenue and Arms. Smith adalah salah satu pelopor sistem ekonomi kapitalisme. Sistem ekonomi ini muncul pada abad 18 di Eropa Barat dan pada abad 19 mulai terkenal di sana (Atmanti, 2017). Ajaran tentang doktrin perekonomian liberal yang berasal dari Adam Smith menandai adanya suatu perubahan yang revolusioner dalam pemikiran ekonomi. Pada masa-masa sebelumnya terutama masa merkantilis, peran negara sangat tinggi atas individuindividu. Akan tetapi, sejak era Smith kepentingan individu lebih diutamakan. Kepentingan negara tidak hanya dinomorduakan, bahkan lebih dari itu negara justru diberi tugas demi menjamin tercapainya kondisi bagi setiap orang untuk bebas bertindak melakukan yang terbaik bagi diri mereka masing-masing (Piliyanti, 2009). Pemikiran Smith antara lain:

1) Sangat mendukung seminimal mungkin campur tangan pemerintah dalam perekonomian. Adanya invisible hand yang membawa perekonomian pada keseimbangan.

2) Perlu adanya spesialisasi atau pembagian kerja agar produktivitas tenaga kerja bertambah.

3) Smith mendukung perdagangan bebas internasional antar negara.

4) Smith menolak kekuatan monopoli yang akan merusak pasar.

5) Menetapkan sistem pajak untuk membiayai pengeluaran publik.

6) Perlunya akumulasi kapital dengan melakukan penghematan dan investasi modal sebagai kunci penting bagi pertumbuhan ekonomi.

7) Jumlah penduduk akan meningkat seiring dengan tingkat upah yang lebih tinggi dari tingkat upah subsisten (Atmanti, 2017). 


\section{DAFTAR PUSTAKA}

Atmanti, H.D. (2017). Kajian Teori Pemikiran Ekonomi Mazhab Klasik dan Relevansinya pada Perekonomian Indonesia . Jurnal Ekonomi dan Bisnis. 2(2), 511-524.

Agustiati. (2009). Sistem Ekonomi Kapitalisme. 1(2), 152-166.

Cholidiyah, Nurul. (2018). Perilaku Produsen Menurut Yusuf Qordhowi dan Karl Marx. LAA MAISYIR. 5(2), 68-69.

Hasan, Z., \& Mahyudi. (2020). Analisis terhadap Pemikiran Ekonomi Kapitalisme Adam Smith. Jurnal Ekonomi dan Hukum Islam. 4(1), 24-34.

Piliyanti, Indah. (2009). Menggugat Sistem Kapitalisme. Jurnal Ekonomi Islam. III(1), 46-55.

Tumbol, C.L., Tewal, B., \& Sepang, J.L. (2015). GAYA KEPEMIMPINAN OTOKRATIS, DEMOKRATIK DAN LAISSEZ FAIRE TERHADAP PENINGKATAN PRESTASI KERJA KARYAWAN PADA KPP PRATAMA MANADO. Jurnal EMBA.2( 1), 38-47. 